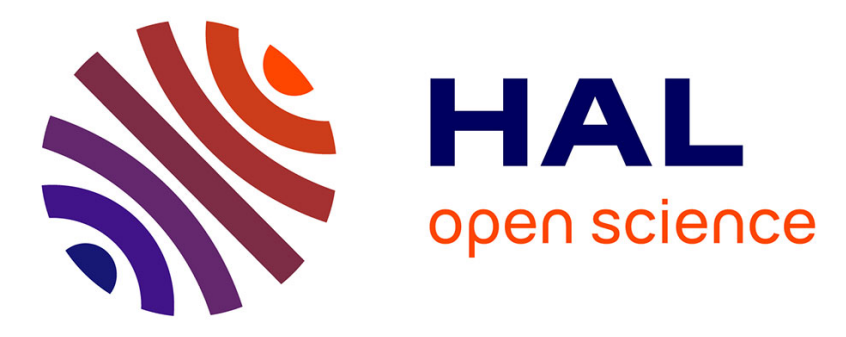

\title{
Carbonylation of Alkyl Radicals Derived from Organosilicates through Visible-Light Photoredox Catalysis
}

Alex Cartier, Etienne Levernier, Vincent Corcé, Takahide Fukuyama, Anne-Lise Dhimane, Cyril Ollivier, Ilhyong Ryu, Louis Fensterbank

\section{To cite this version:}

Alex Cartier, Etienne Levernier, Vincent Corcé, Takahide Fukuyama, Anne-Lise Dhimane, et al.. Carbonylation of Alkyl Radicals Derived from Organosilicates through Visible-Light Photoredox Catalysis. Angewandte Chemie International Edition, 2019, 58 (6), pp.1789-1793. 10.1002/ange.201811858 . hal-02010150

\section{HAL Id: hal-02010150 \\ https://hal.sorbonne-universite.fr/hal-02010150}

Submitted on 26 Aug 2019

HAL is a multi-disciplinary open access archive for the deposit and dissemination of scientific research documents, whether they are published or not. The documents may come from teaching and research institutions in France or abroad, or from public or private research centers.
L'archive ouverte pluridisciplinaire HAL, est destinée au dépôt et à la diffusion de documents scientifiques de niveau recherche, publiés ou non, émanant des établissements d'enseignement et de recherche français ou étrangers, des laboratoires publics ou privés. 


\title{
Carbonylation of Alkyl Radicals Derived from Organosilicates through Visible-Light Photoredox Catalysis
}

\author{
Alex Cartier, ${ }^{\ddagger[\mathrm{a}]}$ Etienne Levernier, ${ }^{\ddagger[\mathrm{b}]}$ Vincent Corcé ${ }^{[\mathrm{b}]}$ Takahide Fukuyama, ${ }^{[\mathrm{[a]}}$ Anne-Lise Dhimane, ${ }^{[\mathrm{b}]}$ \\ Cyril Ollivier, ${ }^{*[b]}$ Ilhyong Ryu, ${ }^{*[a] c]}$ and Louis Fensterbank ${ }^{*[b]}$
}

\begin{abstract}
Primary, secondary and tertiary alkyl radicals, formed by photocatalyzed oxidation of organosilicates, can be involved efficiently in radical carbonylation with carbon monoxide (CO), which leads to a variety of unsymmetrical ketones. This work constitutes the first example of radical carbonylation under a photooxidative regime.
\end{abstract}

Visible-light photoredox catalysis now holds a privileged position in modern radical chemistry. ${ }^{[1,2]}$ Several families of alkyl radical precursors, such as alkylcarboxylates, ${ }^{[3]}$ alkyltrifluoroborates, ${ }^{[4]}$ and alkylsulfinate salts ${ }^{[5]}$ are known to use visible light irradiation to promote the efficient formation of alkyl radical species under photooxidation conditions. Recently, alkyl bis(catecholato)silicates ${ }^{[6]}$ were introduced by the Paris group $^{[7]}$ and later by Molander ${ }^{[8]}$ and others ${ }^{[9]}$ to allow for the smooth generation of a variety of alkyl radicals that includes unstabilized primary radicals, and this enhancement applies to visible light photoredox-catalyzed conditions with $\mathrm{Ru}(\mathrm{II})$ or $\operatorname{Ir}(\mathrm{III})$ salts and even with organic dye 1,2,3,5-tetrakis(carbazol-9-yl)4,6-dicyano-benzene (4CzIPN). ${ }^{[7 b, 10]}$ The generated alkyl radical species can be promptly trapped by several activated alkenes, allylsulfone, ${ }^{[7 \mathrm{~b}, 7 \mathrm{c}]}$ and imines. ${ }^{[11]}$

Radical multicomponent processes are in great demand as they allow the reduction of a number of steps in order to obtain the targeted compounds. ${ }^{[12]}$ In this regard, carbon monoxide (CO) is effective as a donor/acceptor type radical C1 synthon similar to isonitriles. ${ }^{[13,14]}$ Carbonylative couplings for the formation of ketones or esters by radical carbonylations have been extensively investigated by the Osaka group ${ }^{[15]}$ which include photo-induced carbonylation reactions. ${ }^{[15]}$ In those studies organic halides, chalcogenides, and unsaturated C-C

[a] A. Cartier, ${ }^{\left[{ }^{\mp]}\right]}$ Prof. T. Fukuyama, Prof. I. Ryu

Department of Chemistry, Graduate School of Science

Osaka Prefecture University

Sakai, Osaka 599-8531, Japan

E-mail: fukuyama@c.s.osakafu-u.ac.jp ryu@c.s.osakafu-u.ac.jp

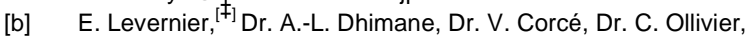
Prof. L. Fensterbank

Sorbonne Université, CNRS

Institut Parisien de Chimie Moléculaire

4 Place Jussieu, CC 229, F-75252 Paris Cedex 05, France

E-mail: cyril.ollivier@sorbonne-universite.fr louis.fensterbank@sorbonne-universite.fr

[c] Prof. I. Ryu

Department of Applied Chemistry

National Chiao Tung University

Hsinchu, Taiwan

E-mail: ryu@c.s.osakafu-u.ac.jp

$\left[{ }^{\ddagger}\right] \quad$ These authors contributed equally to this work. bonds were generally used as the starting radical sources Recently, several groups have applied aryl radical carbonylation to successful photoredox conditions, that follow a reductive photoredox pathway using aryl diazonium salts as aryl radical precursors. For example, Gu, Jacobi Von Wangelin, and Xiao independently reported that ketones and esters can be formed via the photoredox carbonylation of an aryl ring by using $\mathrm{CO}$ either in the presence of eosin $\mathrm{Y}^{[16]}$ or fluorescein as a photocatalyst (Scheme 1 , type A). ${ }^{[17,18]}$

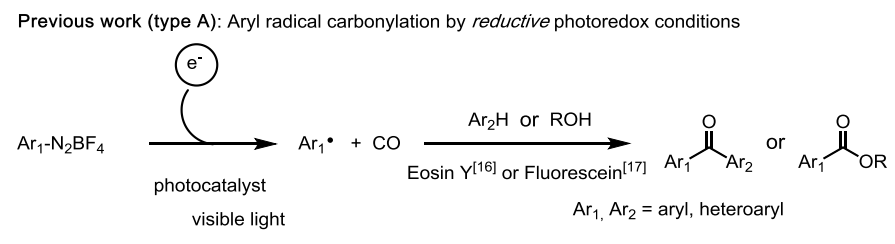

This work (type B): Alkyl radical carbonylation by oxidative photoredox conditions

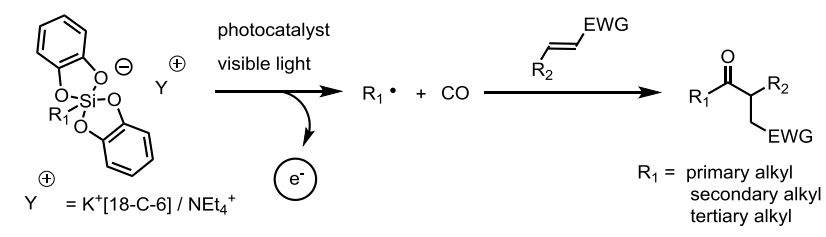

Scheme 1. Photoredox catalysed radical carbonylation under photoreductive conditions (previous work) and under photooxidative conditions (this work).

Ryu and co-workers previously reported three component types of unsymmetrical ketone synthesis for which alkyl halides, $\mathrm{CO}$, and alkenes were reacted typically using tributyltin hydride ${ }^{[19]}$ or tris(trimethylsilyl)silane ${ }^{[20]}$ as a radical mediator. ${ }^{[21]}$ We considered the use alkyl bis(catecholato)silicates as new substrates in this reaction. These are easily prepared from the corresponding alkoxysilanes and trichlorosilanes in a one-pot reaction (see supporting information for more details). They can be conserved weeks on the bench in contact with ambient air. ${ }^{[7-9]}$ They also exhibit relatively low oxidation potentials $(<1 \mathrm{~V} v s$. SCE). Herein we report the first example of oxidative photocatalyzed carbonylative coupling reaction, as a novel three-component carbonylation route to unsymmetrical ketones under mild visible-light photoredox conditions that require no traditional radical mediators (Scheme 1, type B). As ketones are ubiquitous and important in organic chemistry due to their polyvalent reactivity, the development of new methods for their synthesis is still very useful for chemists. ${ }^{[22]}$ Table 1: Optimization of the reaction conditions ${ }^{\text {[a] }}$ 


\begin{tabular}{|c|c|c|c|c|c|}
\hline 1a $0.3 \mathrm{~m}$ & $\ominus^{[18-C-6]}+$ & \multicolumn{2}{|c|}{$\begin{array}{l}\text { Photocatalyst } \\
\mathrm{KH}_{2} \mathrm{PO}_{4} 1.2 \text { equiv } \\
\mathrm{DMF} \\
\text { Blue LED; r.t.; } \\
24 \mathrm{~h} ; \mathrm{CO} \text { (80 atm) }\end{array}$} & \multirow{2}{*}{$\begin{array}{r}\mathbf{3 a} \\
\text { Yield } \mathbf{3} \mathbf{a}^{[\mathrm{b}]} \\
\end{array}$} & \multirow{2}{*}{$\frac{4 a}{\text { Ratio } 3 a: 4 a^{[d]}}$} \\
\hline Entry & Catalyst & [2a] [M] & Time (h) & & \\
\hline 1 & {$[\mathrm{Ir}]^{[\mathrm{e}]}$} & 0.15 & 24 & $58 \%$ & $92: 8$ \\
\hline 2 & $4 \mathrm{Cz} / \mathrm{PN}^{[\mathrm{ff}]}$ & 0.15 & 24 & $69 \%$ & $93: 7$ \\
\hline 3 & none & 0.15 & 24 & $13 \%{ }^{[c]}$ & $75: 25$ \\
\hline 4 & $4 \mathrm{Cz} / \mathrm{PN} \mathrm{N}^{[\mathrm{ff}}$ & 0.02 & 24 & $49 \%$ & $97: 3$ \\
\hline 5 & $4 \mathrm{Cz} I \mathrm{PN} \mathrm{N}^{[\mathrm{ff}]}$ & 0.04 & 24 & $65 \%$ & $97: 3$ \\
\hline 6 & $4 \mathrm{Cz} I \mathrm{PN} N^{[f]}$ & 0.09 & 24 & $71 \%$ & $94: 6$ \\
\hline 7 & $4 \mathrm{Cz} / \mathrm{PN}^{[\mathrm{ff}}$ & 0.09 & 48 & $85 \%$ & $95: 5$ \\
\hline
\end{tabular}

[a] Conditions: potassium [18-Crown-6] bis(catecholato)-cyclohexylsilicate (1a, $0.3 \mathrm{mmol}, 1$ equiv), dimethylmaleate (2a, 2 equiv), photocatalyst (1-2 $\mathrm{mol} \%), \mathrm{KH}_{2} \mathrm{PO}_{4}(0.36 \mathrm{mmol}), \mathrm{CO}(80 \mathrm{~atm}), \mathrm{DMF}(10-3 \mathrm{~mL})$, irradiation by blue LED lamp $(425 \mathrm{~nm})$ for $24-48 \mathrm{~h}$. [b] isolated yield. [c] determined by ${ }^{1} \mathrm{H}$ NMR. [d] determined by $\mathrm{GC}$ of the crude mixture. [e] $\left[\operatorname{lr}\left(\mathrm{dF}\left(\mathrm{CF}_{3}\right) \mathrm{ppy}\right)_{2}(\mathrm{bpy})\right]\left(\mathrm{PF}_{6}\right), 2$ mol\%. [f] $1 \mathrm{~mol} \%$.

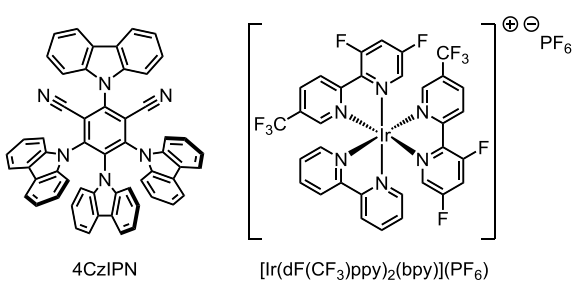

As a model, we first chose to test a three-component coupling reaction comprised of cyclohexyl bis(cathecolato) silicate (1a), CO, and dimethylmaleate (2a). The experiment was carried out in a stainless-steel autoclave equipped with two quartz glass windows that served as a pressure-durable apparatus during light irradiation ( $15 \mathrm{~W}$ blue LED, see the supporting information for details). The results are summarized in Table 1. When a solution of $\mathbf{1 a}, \mathbf{2 a}$, $\left[\operatorname{Ir}\left(\mathrm{dF}\left(\mathrm{CF}_{3}\right) \mathrm{ppy}\right)_{2}(\mathrm{bpy})\right]\left(\mathrm{PF}_{6}\right)(1 \mathrm{~mol} \%)$, and $\mathrm{KH}_{2} \mathrm{PO}_{4}$ (1.2 equiv) in DMF was irradiated for 24 hours under a $\mathrm{CO}$ pressure of $80 \mathrm{~atm}$, the desired reaction proceeded to give the anticipated unsymmetrical ketone $3 \mathrm{a}$ in a $58 \%$ yield after isolation by flash chromatography on silica gel (Table 1 , entry 1). The noncarbonylated product $\mathbf{4 a}$ was the only by-product of the reaction, and was present in only a small amount $(\mathbf{3 a}: \mathbf{4 a}=92: 8)$. To insure effective photoredox catalysis, we used an organic dye, 1,2,3,5-tetrakis-(carbazole-yl)-4-dicyanobenzene (4CzIPN), with a long excited state lifetime $(5.1 \mu \mathrm{s}) .{ }^{[23,7 \mathrm{c}]}$ It also displays interesting photoredox properties $\left(\mathrm{E}_{1 / 2}\left(4 \mathrm{CzIPN}^{*} /[4 \mathrm{CzIPN}]^{-}\right)=\right.$ $+1.59 \mathrm{~V}$ vs. SCE and $\mathrm{E}_{1 / 2}\left(4 \mathrm{CzIPN} /[4 \mathrm{CzIPN}]^{-}\right)=-1.21 \mathrm{~V}$ vs. $\mathrm{SCE}),{ }^{[24]}$ so that this photocatalyst has proven useful for the photooxidation of alkyl bis(catecholato)silicates. ${ }^{[7 \mathrm{~b}, 10 \mathrm{e}]}$ To our delight, using this organic dye we obtained a better yield of $69 \%$ with similar ratios of $\mathbf{3 a}$ and $\mathbf{4 a}(93: 7)$ (Table 1 , entry 2$)$. When the reaction was tested without the use of a photocatalyst, the yield dropped dramatically to $13 \%$ (Table 1, entry 3 ), which suggested the necessity of a photocatalyst. Next, we decreased the concentration of $2 \mathrm{a}$ from $0.15 \mathrm{M}$ to 0.02 and $0.04 \mathrm{M}$. At a lower concentration $(0.02 \mathrm{M})$, the reaction became sluggish and the yield of $3 \mathbf{a}$ was decreased to $49 \%$ (Table 1, entry 4 ). With $2 \mathbf{a}$ at $0.04 \mathrm{M}$, the yield reached $65 \%$ (Table 1 , entry 5 ). In these two cases, the ratio remained excellent $(97: 3)$. When the reaction was carried out with $0.09 \mathrm{M}$ of $\mathbf{2 a}$, we observed an increased yield of product $3 a$ to $71 \%$ with a slightly decreased ratio of 94 : 6 (Table 1, entry 6). Since the reaction of entry 6 remained slow, we extended the reaction time for $48 \mathrm{~h}$, which gave $3 \mathrm{a}$ in an $85 \%$ isolated yield (Table 1 , entry 7 )

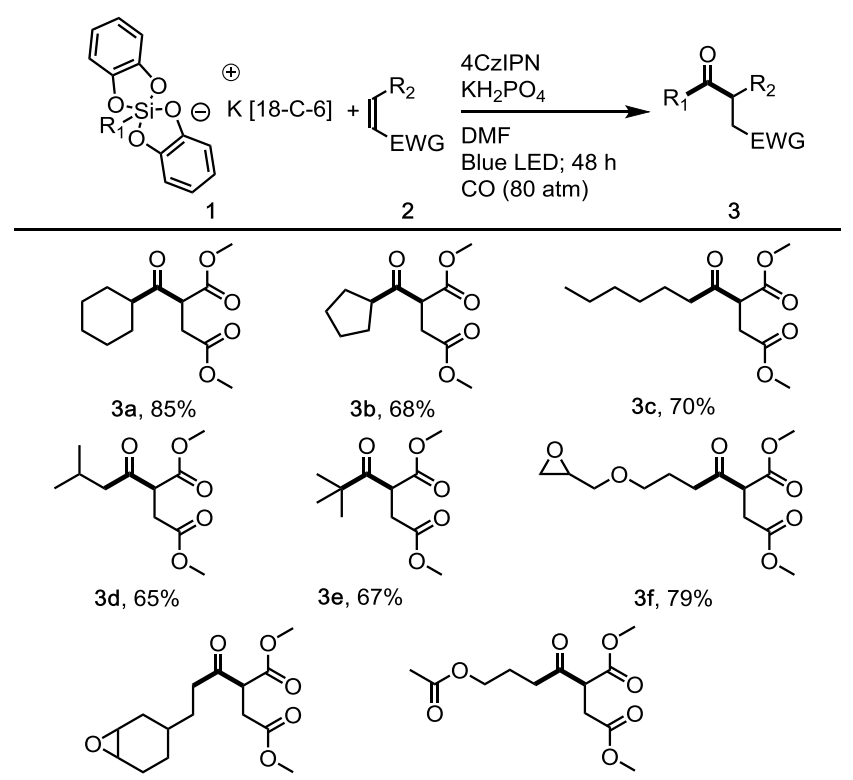

$3 g, 54 \%(80 \%$ after $72 \mathrm{~h})$

3h, $50 \%\left({ }^{1} \mathrm{H}\right.$ NMR $)$

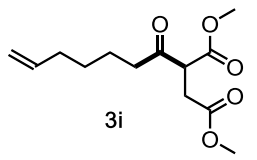<smiles>COC(=O)CC(C(=O)CC1CCCC1)C(=O)OC</smiles>

mixture $3 i: 3 i$ ', $34 \%(46: 54)$<smiles>CC(=O)CCC(=O)C1CCCCC1</smiles>

3j, $80 \%$<smiles>N#CCCC(=O)C1CCCCC1</smiles>

$3 \mathrm{~m}, 81 \%$<smiles>O=C(CCS(=O)(=O)c1ccccc1)C1CCCCC1</smiles>

$3 k, 42 \%$<smiles>COC(=O)CCC(=O)C1CCCCC1</smiles>

3 I, $34 \%$<smiles>COC(=O)CC(C)C(=O)C1CCCCC1</smiles>

$3 p, 78 \%$<smiles>CN(C)C(=O)CCC(=O)C1CCCCC1</smiles>

$3 n, 60 \%$

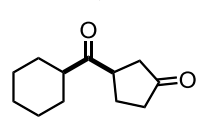

3o, $53 \%$<smiles>CCOC(=O)C(C)C(=O)C1CCCCC1C(=O)C(C)C(C(=O)OCC)C(=O)C1CCCCC1</smiles>

$3 q, 89 \%$

$3 r, 54 \%$

Scheme 2. Scope of the substrates for the three-component reaction leading to unsymmetrical ketones 3

We applied these optimized conditions to the threecomponent synthesis of a series of unsymmetrical ketones $\mathbf{3}$, using a variety of alkyl bis(cathecolato)silicates as substrates (Scheme 2). The carbonylation of the cyclopentyl derivative worked well and led to the corresponding unsymmetrical ketone $\mathbf{3 b}$ in a $68 \%$ yield. Primary radicals furnished good yields, irrespective of the use of a linear alkyl (3c, $70 \%)$ or a branched alkyl (3d, 65\%). The reaction of a tertiary alkylsilicate also gave ketone $3 \mathrm{e}$ in a $67 \%$ yield. Interestingly, the reaction was compatible with a rather sensitive level of functionality, such as 
with an oxirane, and gave the desired product $\mathbf{3 f}$ in a $79 \%$ yield. Product $\mathbf{3 g}$ with an oxabicycloheptyl moiety was obtained in an $80 \%$ yield, albeit with an extended reaction time of 72 hours. The carbonylated adduct $\mathbf{3 h}$, bearing an acetate, appeared unstable and could not be isolated, although it was identified by ${ }^{1} \mathrm{H}$ NMR in the crude reaction mixture $(50 \%)$. The use of the 5hexenyl derivative 1i was expected to provide insight into the rate of carbonylation under these conditions. Interestingly, under the employed conditions, we obtained an almost equimolar mixture of uncyclized $\mathbf{3} \mathbf{i}$ and cyclized $\mathbf{3} \mathbf{i}$ ' in a $34 \%$ yield, with a crude NMR chart that suggested other by-products had formed via carbonylation. ${ }^{[25]}$

Next, we investigated the compatibility of a variety of activated alkenes as radical acceptors $(\mathbf{2 a - k})$ by using the threecomponent transformation (Scheme 2). 1,4-Dicarbonyl derivatives still remain challenging to access. ${ }^{[26]}$ Gratifyingly, methyl vinyl ketone $\mathbf{2 b}$ was successfully used in the threecomponent reaction with $\mathrm{CO}$ and bis(catecholato-cyclohexyl)silicate $\mathbf{1 a}$ to give the corresponding 1,4-diketone $\mathbf{3 j}$ in $80 \%$ yield. By contrast, the reaction of vinylsulfone $2 \mathrm{c}$, and methyl acrylate $\mathbf{2 d}$ gave the carbonylation products $\mathbf{3 k}$ and $\mathbf{3} \mathbf{I}$ in rather moderate yields (42 and $34 \%$, respectively). When we used acrylonitrile, the expected product $\mathbf{3 m}$ was obtained in an excellent yield of $81 \%$. The compound $\mathbf{3 n}$, obtained from the $\mathrm{N}, \mathrm{N}$-dimethylacrylamide $\mathbf{2 f}$, was isolated in a $60 \%$ yield. Cyclopentenone $\mathbf{2 g}$ led to the formation of diketone $\mathbf{3 0}$ in a $53 \%$ yield. Interestingly, $\beta$-alkyl-substituted, $\alpha, \beta$-unsaturated carbonyl compounds capably underwent the present transformation. Thus methyl crotonate $\mathbf{2 h}$ gave the corresponding 4-keto ester $3 p$ in a $78 \%$ yield. The reaction of diethyl 2 -ethylidenemalonate $2 \mathbf{i}$ gave the expected product $\mathbf{3 q}$ in an $89 \%$ yield. The reaction of butyl methacrylate $2 \mathbf{j}$ gave the corresponding 4 -keto ester $3 \mathbf{r}$ in a $54 \%$ yield. The reaction of $\mathbf{1 a}$ with $\mathrm{CO}$ in the presence of disulfonylethene $\mathbf{2 k}$, gave non-carbonylated adduct $\mathbf{4 s}$ in a $76 \%$ yield. Disulfonylethylene $\mathbf{2 k}$ is such a good radical acceptor that a direct addition of a cyclohexyl radical proceeded.

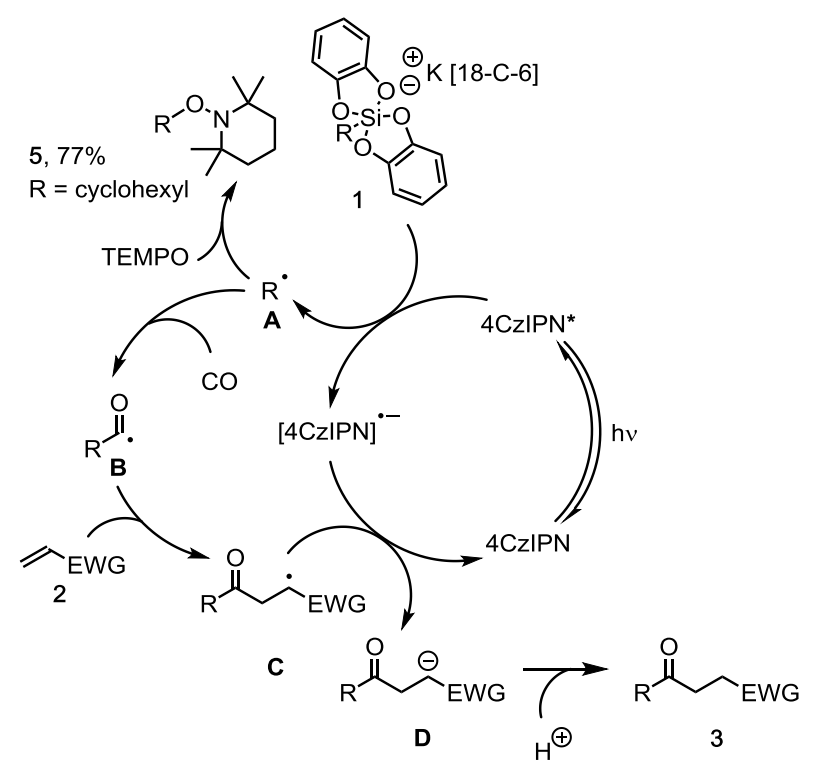

Scheme 3. Proposed mechanism

We proposed the overall mechanism illustrated in Scheme 3. In the first step, the photocatalyst is excited under visible-light irradiation. A SET oxidation of the alkyl bis(catecholato)silicate 1 by the excited ${ }^{*} 4 \mathrm{CzIPN},{ }^{[10]}$ leads to the reduced species [4CzIPN] $]^{-}$and to the formation of the alkyl radical $\mathbf{A}$ via homolytic cleavage of the $\mathrm{C}$-Si bond of the silicate radical. ${ }^{[7-9]}$ Alkyl radical $\mathbf{A}$ reacts with $\mathrm{CO}$ to form the acyl radical $\mathbf{B},{ }^{[14]}$ which adds to the acceptor alkene $\mathbf{2}$ to provide adduct radical $\mathbf{C}$. The latter would be reduced by [4CzIPN] $]^{-}$to afford the stabilized carbanionic species $\mathbf{D}$ and regenerate the photocatalyst in its ground state, thus closing the catalytic cycle and ensuring its propagation. Finally, protonation of $\mathbf{D}$ by $\mathrm{KH}_{2} \mathrm{PO}_{4}$ yields the final product 3.

To support this hypothetical mechanism, we conducted several experiments (see the supporting information for details). Fluorescent quenching studies of ${ }^{*} 4 \mathrm{CzIPN}$ by silicate $1 \mathrm{a}$ in the absence of $\mathrm{CO}$ showed a decrease of the fluorescent intensity upon gradual addition of $1 \mathrm{a}$. The quenching rate constant $\mathrm{kq}$ from the Stern-Volmer equation was determined to be $1.37 \times 10^{8}$ $\mathrm{mol}^{-1} \cdot \mathrm{L} \cdot \mathrm{S}^{-1}$ (in DMF), a value consistent with another determination in DMSO $\left(k q=2.5 \times 10^{7} \mathrm{M}^{-1} \cdot \mathrm{s}^{-1}\right)$ by Molander. ${ }^{[27]}$ Based on the redox potentials differences between ${ }^{*} 4 \mathrm{CzIPN}$ $\left(\mathrm{E}_{1 / 2}\left(4 \mathrm{CzIPN}^{*} /[4 \mathrm{Cz} \mathrm{IPN}]^{-}\right)=+1.59 \mathrm{~V}\right.$ vs. SCE) ${ }^{[1 \mathrm{ff}]}$ and silicate $1 \mathrm{a}$ $(\text { Eox }=+0.69 \vee \text { vs. SCE })^{[7 c]}$, a SET consisting in the reductive quenching of the photoexited photocatalyst ${ }^{*} 4 \mathrm{CzIPN}$ by silicate $\mathbf{1 a}$ is presumably involved. This was confirmed by the reaction of cyclohexylsilicate 1a with $\mathrm{CO}$, in the presence of 2.2 equiv. of TEMPO which led to the exclusive formation of the noncarbonylated TEMPO adduct 5 in $77 \%$ yield, thus highlighting the formation of radical intermediates of type A. A "light/dark" experiment was also conducted in the absence of $\mathrm{CO}$ and it appears that the product formation occurs only during periods of light irradiation. This result might support the catalytic mechanism shown in Scheme $3 .^{[28]}$ To ensure that no short radical chain occurs, we measured quantum yields of the reaction of silicate 1a with different acceptors in the presence of $4 \mathrm{CzIPN}$. We obtained a quantum yield of 0.066 in the conjugate addition with maleate and 0.33 for the allylation reaction with 2phenylallyl p-tolyl sulfone with $4 \mathrm{CzIPN}$. These findings show that the present mechanism does not follow a radical chain pathway but most likely a closed photoredox loop, as depicted in Scheme 3.

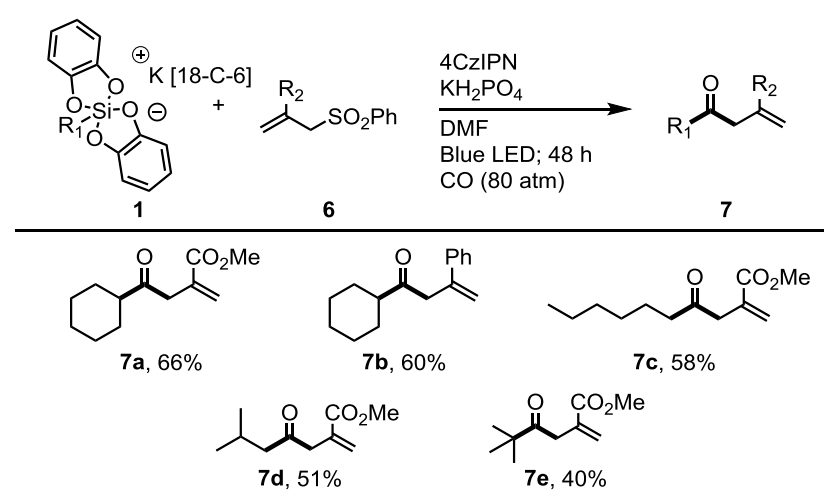

Scheme 4. Three-component reaction leading to unsaturated ketones 7

Next, we focused on the behavior of various silicates towards carbonylative radical allylation with various allylsulfones (6a-b) (Scheme 4), for which previous work used allyltin as a radical acceptor. ${ }^{[19 a]}$ The reaction of $\mathbf{1 a}$ with $\mathrm{CO}$ and allylsulfone 6b, which bears a methoxycarbonyl group at the 2 position, returned $\beta, \gamma$-unsaturated ketone $7 \mathrm{a}$ in a $66 \%$ yield. When phenylallylsulfone $\mathbf{6 b}$ was reacted with cyclohexylsilicate $\mathbf{1 a}$ and 
CO, it gave the expected enone $\mathbf{7 b}$ in a $60 \%$ yield. Primary radicals are good substrates for the present radical allylation regardless of whether it is a linear alkyl (7c,58\%), or a branched alkyl $(\mathbf{7 d}, 51 \%)$. The reaction with a tertiary alkylsilicate gave the desired enone $7 e$ in a $40 \%$ yield together with a noncarbonylated addition product. These allylation reactions followed the pattern of the mechanism reported in Scheme 3, in which the photocatalyst was regenerated by a reduction of the phenylsulfonyl radical to a phenylsulfinate anion. ${ }^{[7 c]}$ The ketones formed herein could be useful scaffolds. For instance, 1,4 ketone 3j could be used through a Paal-Knorr reaction for the synthesis of pyrroles or thiophenes. These heteroaromatics can be found in many natural products but also in biological active compounds such as HMG-CoA reductase inhibitors and hepatitis $C$ virus polymerase inhibitors. ${ }^{[29]}$

In summary, herein, we described an oxidative photoredox catalysis combined with radical carbonylation chemistry, for the first time. The present reaction protocol was based on the use of an inexpensive organic dye, $4 \mathrm{CzIPN}$, as a photocatalyst and on a wide range of alkyl bis(catecholato)silicates that were used as alkyl radical precursors under a $\mathrm{CO}$ atmosphere, which afforded efficient access to a variety of functionalized unsymmetrical ketones including $\beta, \gamma$-unsaturated ketones. These results demonstrate the plausibility of other photocatalyzed radical carbonylation reactions under oxidative regimes that we are now exploring in our laboratory.

\section{Acknowledgements}

This work was supported by the Grant-in-Aid for Scientific Research (A) (No. 26248031) and (C) (No. 17K05866) from the JSPS, and Scientific Research on Innovative Areas 2707: Middle molecular strategy (No. 15H05850) from the MEXT. We thank Sorbonne University, ANR-17-CE07-0018 HyperSilight (PhD grant to E.L.).

\section{Conflicts of interest}

None to declare.

Keywords: carbonylation - three-component reaction • photocatalysis $\cdot$ radicals $\cdot$ silicates

1 For selected reviews, see: a) L. Marzo, S. K. Pagire, O. Reiser, B. König, Angew. Chem. Int. Ed, 2018, 57, 10034-10072; Angew. Chem. 2018, 130, 10188-10228; b) J. K. Matsui, S. B. Lang, D. R. Heitz, G. A. Molander, ACS Catal. 2017, 7, 2563-2575; c) N. A. Romero, D. A. Nicewicz, Chem. Rev., 2016, 116, 10075-10166; d) S. Poplata, A. Tröster, Y-Q. Zou, T. Bach, Chem. Rev. 2016, 116, 9748-9815; e) K. Nakajima, Y. Miyake, Y. Nishibayashi, Acc. Chem. Res. 2016, 49, 1946-1956; f) D. Ravelli, S. Proti M. Fagnoni, Chem. Rev. 2016, 116, 9850-9913; g) T. P. Yoon, Acc. Chem. Res., 2016, 49, 2307-2315; h) J.-R. Chen, X.-Q. Hu, L.-Q. Lu, W.-J. Xiao, Acc. Chem. Res., 2016, 49, 1911-1923; i) J.-P. Goddard, C. Ollivier, L. Fensterbank, Acc. Chem. Res., 2016, 49, 1924-1936; j) T. Koike, M. Akita, Inorg. Chem. Front. 2014, 1, 562-576; k) C. K. Prier, D. A. Rankic, D. W. C. MacMillan, Chem. Rev. 2013, 113, 5322-5363; I) J. M. R. Narayanam, C. R. J. Stephenson, Chem. Soc. Rev., 2011, 40, 102-103.

2 For recent books, see: a) Chemical Photocatalysis, Eds. B. König, DeGruyter Berlin, 2013; b) Photochemically generated intermediates in Synthesis, Eds A. Albini, M. Fagnoni, Wiley, Hoboken, 2013; c) Visible Light Photocatalysis in Organic Chemistry Stephenson, C.; Yoon, T.; MacMillan, D.W. C. Eds. Wiley-VCH 2018.

3 a) S. J. MacCarver, J. X. Qiao, J. Carpenter, R. M. Borzirelli, M. A. Poss, M. D. Eastgate, M. M. Miller, D. W. C. MacMillan, Angew.
Chem. Int. Ed 2017, 56, 728-732; Angew. Chem. 2017, 129, 746-750; b) Z. Zuo, H. Cong, W. Li, J. Choi, G. C. Fu, D. W. C. MacMillan, J. Am. Chem. Soc. 2016, 138, 1832-1835; c) C. C. Nawrat, C. R Jamison, Y. Slutskyy, D. W. C. MacMillan, L. E. Overman, J. Am Chem. Soc. 2015, 137, 11270-11273; d) A. Noble, D. W. C. MacMillan, J. Am. Chem. Soc. 2014, 136, 11602-11605.

4 a) T. Koike, M. Akita, Org. Biomol. Chem. 2016, 14, 6886-6890; b) Y Li, K, Miyazawa, T. Koike, M. Akita, Org. Chem. Front. 2015, 2, 319323; c) Y. Yasu, T. Koike, M. Akita, Adv. Synth. Catal., 2012, 354, 3414-3420.

5 T. Knauber, R. Chandrasekaran, J. W. Tucker, J. M. Chen, M. Reese, D. A. Rankic, N. Sach, C. Helal, Org. Lett., 2017, 19, 6566-6569.

6 C. L. Frye, J. Am. Chem. Soc. 1964, 86, 3170-3171.

7 a) L. Chenneberg, C. Lévêque, V. Corcé, A. Baralle, J.-P. Goddard, C. Ollivier, L. Fensterbank, Synlett 2016, 27, 731-735; b) C. Lévêque, L. Chenneberg, V. Corcé, C. Ollivier, L. Fensterbank, Chem. Comm. 2016, 52, 9877-9880; c) V. Corcé, L.-M. Chamoreau, E. Derat, J.-P. Goddard, C. Ollivier, L. Fensterbank, Angew. Chem., Int. Ed. 2015, 54, 11414-11418; Angew. Chem. 2015, 127, 11576-11580.

8 M. Jouffroy, D. N. Primer, G. A. Molander, J. Am. Chem. Soc. 2016, 138, 475-478.

9 a) K. D. Raynor, G. D. May, U. K. Bandarage, M. J. Boyd, J. Org. Chem. 2018, 83, 1551-1557; b) T. Guo, X. Liu, Y. Fang, X. Jin, Y. Yang, Y. Li, B. Chen, M. Ouyang, Adv. Synth. Catal. 2018, 360, 1-6.

10 For recent examples of reactions using 4 CzIPN as photocatalyst, see: a) X. Wentao, J. Ma, X.-A. Yuan, J. Dai, J. Xie, C. Zhu, Angew. Chem. Int. Ed., 2018, 57, 10357-10361; Angew. Chem., 2018, 130, 1051410518; b) F. L. Vaillant, M. Garreau, S. Nicolai, G. Gryn'ova, C. Corminboeuf, J. Waser, Chem. Sci. 2018, 9, 5883- 5889 ; c) R. Zhou, Y. Y. Goh, H. Liu, H. Tao, L. Li, J. Wu, Angew. Chem. Int. Ed., 2017, 56, 16621-16625; Angew. Chem., 2017, 129, 16848-16852; d) H. Huang, X. Li, C. Yu, Y. Zhang, P. S. Mariano, W. Wang, Angew Chem. Int. Ed., 2017, 56, 1500-1505; Angew. Chem., 2017, 129, 1522-1527; e) H. Huang, C. Yu, Y. Zhang, Y. Zhang, P. S. Mariano, W. Wang, J. Am. Chem. Soc., 2017, 139, 9799-9802; f) B. A. Vara, M. Jouffroy, G. A. Molander, Chem. Sci. 2017, 8, 530-535.

11 N. R. Patel, C. B. Kelly, A. P. Siegenfeld, G. A. Molander, ACS Catal. 2017, 7, 1766-1770.

12 For selected books and reviews, see: a) A. P. Taylor, R. P. Robinson, Y. M. Fobian, D. C. Blakemore, L. H. Jones, O. Fadeyi, Org, Biomol. Chem. 2016, 14, 6611-6637; b) R. C. Cioc, E. Ruijter, R. V. A. Orru, Green Chem. 2014, 16, 2958-2975; c) V. Liautard, Y. Landais, in Multicomponent Reactions, Eds. Zhu, J., Wang, Q., Wang, M. X., Wiley, 2nd Edition, 2014, 401-438; d) A. Dömling, W. Wang, K. Wang Chem. Rev. 2012, 116, 3083-3135; e) C. de Graff, E. Ruijter,. V. A. Orru, Chem. Soc. Rev. 2012, 41, 3969-4009; f) H. Pellissier, Adv. Synth. Catal. 2012, 354, 237-294; h) B. B. Touré, D. G. Hall, Chem. Rev., 2009, 109, 4439-4486; i) B. Ganem, Acc. Chem. Res. 2009, 42 463-472; k) M. Tojino, I. Ryu in Multicomponent Reaction Eds. J. Zhu, H. Bienaymé, Wiley-VCH, Weinheim, 2005, 169-198.

13 For reviews on radical carbonylation, see: b) I. Ryu, Y. Uenoyama, H. Matsubara, Bull. Chem. Soc. Jpn. 2006, 79, 1476-1488; c) I. Ryu, Chem. Rec., 2002, 2, 249-258; d) I. Ryu, Chem. Soc. Rev. 2001, 30, 16-25; e) I. Ryu, N. Sonoda, D. P. Curran, Chem. Rev. 1996, 96, 177 194; f) I. Ryu, N. Sonoda, Angew. Chem. Int. Ed. Engl. 1996, 35, 1050-1066, Angew. Chem 1996, 108, 1140-1157.

14 For a review on acyl radicals, see: C. Chatgilialoglu, D. Crich, M. Komatsu, I. Ryu, Chem. Rev. 1999, 99, 1991-2070.

15 (a) H. Matsubara, T. Kawamoto, T. Fukuyama, I. Ryu, Acc. Chem Res., 2018, 51, 2023-2035; (b) S. Sumino, A. Fusano, T. Fukuyama, I. Ryu, Acc. Chem. Res. 2014, 47, 1563-1574. Also see some recent work of radical carbonyalation: (c) T. Kawamoto, A. Sato, I. Ryu, Chem. Eur. J., 2015, 21, 14764-14767; (d) S. Sumino, T. Ui, Y. Hamada, T. Fukuyama, I. Ryu, Org. Lett., 2015, 17, 4952-4955; (e) T. Kippo, K. Hamaoka, I. Ryu, J. Am. Chem. Soc., 2013, 135, 632-635; (f) T. Fukuyama, N. Nakashima, T. Okada, I. Ryu, J. Am. Chem. Soc. 2013, 135, 1006-1008.

16 a) L. Gu, C. Jin, L. Jiyan, GreenChem 2015, 17, 3733-3736; b) M. Majek, A. Jacobi von Wangelin, Angew. Chem. Int. Ed. 2015, 54, 2270-2274; Angew. Chem. 2015, 127, 2298-2302.

17 W. Guo, L.-Q. Lu, Y. Wang, Y.-N. Wang, J.-R. Chen, W.-J. Xiao, Angew. Chem. Int. Ed., 2015, 54, 2265-2269; Angew. Chem., 2015 127, 2293-2297.

18 For flow version of an annulative carbonylation process, see: $\mathrm{N}$. Micic, A. Polyzos, Org. Lett. 2018, 20, 4663-4666 
19 a) I. Ryu, T. Niguma, S. Minakata, M. Komatsu, Z. Luo, D. P. Curran, Tetrahedron Lett. 1999, 40, 2367-2370; b) I. Ryu, H. Yamazaki, K. Kusano, A. Ogawa, N. Sonoda, J. Am. Chem. Soc. 1991, 113, 85588560.

20 a) I. Ryu, K. Nagahara, A. Kurihara, M. Komatsu, N. Sonoda, J. Organomet. Chem. 1997, 548, 105-107; b) I. Ryu, M. Hasegawa, A Kurihara, A. Ogawa, S. Tsunoi, N. Sonoda, Synlett 1993, 2, 143-145. For a review on TTMS, see: c) C. Chatigilaloglu, C. Ferreri, Y. Landais, V. I. Timokhin, Chem. Rev. 2018, 118, 6516-6572.

21 For decatungstate ion catalyzed $\mathrm{C}-\mathrm{H}$ carbonylation, see: (a) $\mathrm{M}$. Okada, T. Fukuyama, K. Yamada, I. Ryu, D. Ravelli, M. Fagnoni, Chem. Sci., 2014, 5, 2893-2898; I. Ryu, A. Tani, T. Fukuyama, D. Ravelli, S. Montanaro, M. Fagnoni, Org. Lett., 2013, 15, 2554-2557; (c) I. Ryu, A. Tani, T. Fukuyama, D. Ravelli, M. Fagnoni, A. Albini, Angew. Chem. Int. Ed. 2011, 50, 1869-1872, Angew. Chem. 2011, 123, 1909-1912.

22 For selected recent exemples of unsymmetrical ketones synthesis, see: a) M. Zhang, J. Xie, C. Zhu, Nat. Commun., 2018, 9, 3517-3527; b) L. Anthore-Dalion, Q. Liu, S. Z. Zard, J. Am. Chem. Soc., 2016, 138, 8404-8407; c) W. S. Bechara, G. Pelletier, A. B. Charette, Nat Chem., 2012, 4, 228-234.

23 H. Uoyama, K. Goushi, K. Shizu, H. Nomura, C. Adachi, Nature 2012 , 492, 234-238.

24 a) J. Luo, J. Zhang, ACS Catal. 2016, 6, 873-877; For a reevaluation of the reduction and oxidation potentials of the excited state of $4 \mathrm{CzIPN}$, see 10 .

25 For the rate constants of addition of primary radicals on $\mathrm{CO}\left(\mathrm{k}_{\mathrm{co}}\right)$, see: a) K. Nagahara, I. Ryu, N. Kambe, M. Komatsu, N. Sonoda, J. Org. Chem. 1995, 60, 7384-7385. Based on the ratio of observerd products $3 \mathbf{j}: 3 \mathbf{j}$ ', we have $\mathrm{k}_{\mathrm{cycl}}=\mathrm{k}_{\mathrm{co}}[\mathrm{CO}]=2 \times 10^{5} \mathrm{~s}^{-1}$. For the rate of the 5-exo-trig cyclization, see: b) C. Chatgilialoglu, K. U. Ingold, J. C. Scaiano, J. Am. Chem. Soc. 1981, 103, 7739-7742.

26 a) Organic Synthesis: The Disconnection Approach, second edition, Eds S. Warren, P. Wyatt, John Wiley and Sons, 2011. b) For a discussion of this, see: D. Kaldre, I. Klose, N. Maulide, Science 2018 361, 664-667.

27 J. P. Phelan, S. B. Lang, J. S. Compton, C. B. Kelly, R. Dykstra, O. Gutierrez, G. A. Molander, J. Am. Chem. Soc. 2018, 140, 8037-8047.

28 For practical reasons, the "light/dark" experiment was conducted without $\mathrm{CO}$. We assumed that with or without $\mathrm{CO}$, the reaction follows the same kind of photoredox catalyzed mechanism. However, a radical chain mechanism involving SET between intermediate $\mathbf{C}$ and silicate 1 cannot be discarded just from this single experiment, see: $\mathrm{M}$ A. Cismesia, T. P. Yoon, Chem. Sci. 2015, 6, 5426-5434.

29 a) D. Barnes-Seeman, C. Boiselle, C. Capacci-Daniel, R. Chopra, K; Hoffmaster, C. T. Jones, M. Kato, K. Lin, S. Ma, G. Pan, L. Shu, J. Wang, L. Whiteman, M. Xu, R. Zheng, J. Fu, Bioorg. Med. Chem. Lett. 2014, 24, 3979-3985; b) B. D. Roth, D. F. Ortwine, M. L. Hoefle, C. D Stratton, D. R. Sliskovic, M. W. Wilson, R. S. Newton, J. Med. Chem 1990, 33, 21-31. 
